\title{
Orteronel Switch Maintenance Therapy in Metastatic Castration Resistant Prostate Cancer After First-Line Docetaxel: A Multicenter, Randomized, Double-Blind, Placebo-Controlled Trial (SAKK 08/I I)
}

\author{
Richard Cathomas, ${ }^{1 *}$ Simon J. Crabb, ${ }^{2}$ Michael Mark, ${ }^{1}$ Ralph Winterhalder, ${ }^{3}$ \\ Christian Rothermundt, ${ }^{4}$ Tony Elliott, ${ }^{5}$ Philippe von Burg, ${ }^{6}$ Heike Kenner, ${ }^{7}$ Stefanie Hayoz, ${ }^{7}$ \\ Simona Berardi Vilei, ${ }^{7}$ Daniel Rauch, ${ }^{8}$ Enrico Roggero, ${ }^{9}$ Markus G. Mohaupt, ${ }^{10}$ \\ Jürg Bernhard, ${ }^{11}$ Gabriela Manetsch, ${ }^{1}$ and Silke Gillessen ${ }^{4}$ for the Swiss Group for Clinical \\ Cancer Research SAKK \\ 'Oncology/Hematology, Kantonsspital Graubünden, Chur, Switzerland \\ ${ }^{2}$ Cancer Sciences Unit, University of Southampton, Southampton, United Kingdom \\ ${ }^{3}$ Department of Oncology Kantonsspital Luzern, Luzern, Switzerland \\ ${ }^{4}$ Department of Oncology/Hematology, Kantonsspital St. Gallen, St. Gallen, Switzerland \\ ${ }^{5}$ Department of Oncology, The Christie Clinic, Manchester, United Kingdom \\ ${ }^{6}$ Department of Oncology, Kantonsspital Aargau, Aarau, Switzerland \\ ${ }^{7}$ SAKK Coordinating Center, Bern, Switzerland \\ ${ }^{8}$ Oncology, Hospital Simmental, Thun, Switzerland \\ ${ }^{9}$ Department of Oncology, Bellinzona IOSI, Bellinzona, Switzerland \\ ${ }^{10}$ Department of Nephrology, Hypertension and Clinical Pharmacology, University of Bern, Bern, Switzerland \\ "International Breast Cancer Study Group Coordinating Center Bern and University Hospital, Inselspital Bern, \\ Switzerland
}

BACKGROUND. We tested whether a switch maintenance treatment with orteronel, an oral inhibitor of androgen biosynthesis, prolongs disease control in men with metastatic castrationresistant prostate cancer (mCRPC) after documented disease stabilization with docetaxel.

METHODS. Men with $\mathrm{mCRPC}$ and non-progressive disease after a cumulative dose of $\geq 300 \mathrm{mg} / \mathrm{m}^{2}$ docetaxel for first line treatment were randomized 1:1 to receive orteronel

\footnotetext{
Grant sponsor: Takeda Millennium (The Takeda Oncology Company); Grant sponsor: Swiss State Secretariat for Education, Research and Innovation (SERI).

Trial Registration: This trial is registered with ClinicalTrials.gov with the identifier Trial ID: NCT01707966.

Presented in part at the European Cancer Congress in Vienna 26.09.2015.

Conflicts of interest: Richard Cathomas reports advisory role for Astellas, Janssen Cilag, Sanofi Aventis, Bayer, Pfizer, Novartis, and research grants from Janssen Cilag and Sanofi Aventis. Simon Crabb reports advisory role for Astellas, Bayer, Sanofi, Janssen, and grants from AstraZeneca. Christian Rothermundt reports advisory role for Pfizer, GSK, Novartis. Enrico Roggero reports advisor role for Bayer, Pfizer, Astellas. Silke Gillessen reports advisory role or speakers bureau for Astellas, Amgen, Bayer, CureVac, Dendreon, ESSA Pharmaceuticals, Janssen Cilag, Janssen Diagnostics, Millennium, Nektar Therapeutics, Novartis, Orion Pharma, Pfizer, ProteoMediX, Sanofi Aventis. In addition, Silke Gillessen has a patent WO 2009138392 A1 pending.

${ }^{*}$ Correspondence to: Richard Cathomas, MD, Division of Oncology/Hematology, Kantonsspital Graubünden, Loestrasse 170, CH-7000 Chur, Switzerland. E-mail: richard.cathomas@ksgr.ch

Received 16 April 2016; Accepted 12 July 2016

DOI 10.1002/pros.23236

Published online in Wiley Online Library

(wileyonlinelibrary.com).
}

(c) 2016 Wiley Periodicals, Inc. 
$300 \mathrm{mg}$ twice daily or placebo. The primary endpoint was event-free survival (EFS) defined as the time from randomization to death or the combination of at least two of radiographic, clinical, or PSA progression. Ninety-six patients per arm were planned to demonstrate an improvement of median EFS from 4 months on placebo to 6.7 months on orteronel (hazard ratio (HR) 0.6 ; type I error $5 \%$ and power $90 \%$ ).

RESULTS. Forty-seven patients ( 23 orteronel, 24 placebo) were randomized before premature closure of the trial because of discontinuation of clinical development of orteronel. Median EFS was 8.5 months with orteronel and 2.9 months with placebo $(P=0.001$; HR 0.32 ; 95\%CI 0.15-0.65). Median radiographic progression-free survival (rPFS) was 8.5 and 2.8 months $(P=0.02$; HR $0.42 ; 95 \%$ CI $0.20-0.91)$ in the orteronel and placebo arm, respectively. PSA decline $\geq 50 \%$ was seen in $57 \%$ on orteronel and $4 \%$ on placebo. Toxicity was mainly mild, one patient on orteronel developed transient grade 3 adrenal insufficiency and one grade 4 pneumonitis.

CONCLUSIONS. Orteronel significantly prolongs EFS in men with mCRPC who achieve disease stabilization with docetaxel. The concept of switch maintenance therapy in mCRPC warrants further research. Prostate $\quad$ (C) 2016 Wiley Periodicals, Inc.

KEY WORDS: Castration-resistant prostate cancer; orteronel; maintenance; docetaxel

\section{INTRODUCTION}

Chemotherapy with docetaxel in combination with prednisone was the first systemic treatment demonstrating a significant survival benefit in patients with metastatic castration resistant prostate cancer (mCRPC) [1]. Novel androgen receptor pathway inhibitors (API) such as abiraterone acetate and enzalutamide were recently found to prolong overall survival (OS) in patients with progressive mCRPC after docetaxel chemotherapy and also in chemotherapy-naïve patients [2-5].

Orteronel is a novel API that blocks the synthesis of gonadal and adrenal androgens by blockade of CYP17. Orteronel has been tested in two phase III clinical trials demonstrating clinical efficacy with significant improvement of radiographic progression free survival, PSA response and good tolerance but did not significantly prolong overall survival $[6,7]$.

Chemotherapy with docetaxel can only be administered for a limited time period due to cumulative toxicity. Patients achieving disease response or stabilization on docetaxel are currently observed until evidence of disease progression. In all reported mCRPC phase III trials enrolling patients after prior docetaxel chemotherapy, subsequent treatment was commenced in the setting of progressive disease. Trials in other malignancies, for example, lung cancer have shown that initiating an effective and well tolerated treatment immediately at the end of first-line chemotherapy (so called switch maintenance therapy) improves progressionfree and overall survival $[8,9]$. This may also hold true for early administration of active and well tolerated novel hormonal agents in men with $\mathrm{mCRPC}$, but has not yet been tested in a prospective randomized fashion.
The aim of this investigator-initiated trial was to test the hypothesis that starting orteronel directly after disease stabilization with docetaxel in men with mCRPC could prolong event-free survival (EFS) and consequently maintain quality of life (QoL).

\section{PATIENTS AND METHODS \\ Trial Design and Conduct}

The trial was planned as an international, multicenter, randomized, double-blind, placebo-controlled, phase III trial. The trial was performed in 17 hospitals in Switzerland and the United Kingdom.

Computer generated randomization was centralized at the SAKK Coordinating Center. Patients were stratified according to participating site, WHO performance status ( $0-1$ vs. 2 ) and localization of metastases (bone only vs. presence of other metastases) using the minimization method in a 1:1 ratio.

Allocation of drug code numbers to the patient was performed by the pre-wholesaler and directly communicated to the sites. Patients, investigators, site staff, monitors, and a designated statistician were blinded to treatment allocation. For the case that emergency unblinding was necessary, a scratch off card was provided.

The trial was performed in accordance with the Declaration of Helsinki [10], the Guidelines of Good Clinical Practice issued by ICH [11] and the Swiss and European regulatory authorities' requirements [12-16]. It was approved by the local ethics review boards of all participating centers and Swissmedic.

The trial was registered at the National Institute of Health (www.clinicaltrial.gov; identifier number: Trial ID: NCT01707966). 


\section{Patients}

Eligible patients were $\geq 18$ years, castration resistant, had WHO performance status $\leq 2$, and radiographically documented metastatic adenocarcinoma of the prostate. They were randomized within 3-6 weeks after the last dose of docetaxel chemotherapy having achieved at least disease stabilization defined as no evidence of disease progression according to PCWG2 [17]. Patients must have received a cumulative dose of docetaxel of $\geq 300 \mathrm{mg} / \mathrm{m}^{2}$. Adequate laboratory values for blood count, liver, and renal function were required. Patients were excluded in the case of prior treatment with CYP17 inhibitors (including ketoconazole), prior chemotherapy other than docetaxel, uncontrolled arterial hypertension despite appropriate therapy, QTc interval $>460 \mathrm{msec}$, or clinically relevant cardiac disease. Written informed consent was obtained from all patients.

\section{Treatment and Assessments}

Treatment consisted of orteronel $300 \mathrm{mg}$ BID (three tablets of $100 \mathrm{mg}$ BID) or placebo (three tablets BID) to be taken continuously with or without food each day $12 \mathrm{hr}$ apart in a 28-day cycle. No regular prednisone was administered. All patients received best supportive care and continued treatment on LHRH analogues. Use of bone targeted agents such as bisphosphonates or denosumab (but not Radium-223) was permitted.

Patients had baseline imaging with computed tomography (chest, abdomen, pelvis) and a bone scan. The same imaging was repeated every 12 weeks. Clinical and laboratory investigations were performed every 2 weeks for the first two cycles and every 4 weeks thereafter. PSA was measured every 4 weeks. All patients had baseline evaluation of cardiac function and ECG was repeated every 12 weeks.

For the QoL assessment a questionnaire including FACT-P [18] including the FACT-P PCS pain subscale and a global indicator for treatment burden [19] was completed at baseline and on day 1 of each cycle for a maximum of seven cycles. Collection of spot urine was performed at baseline and on day 1 of cycle 4 (Swiss sites only). Urinary steroid metabolites were analyzed by gas chromatography-mass spectrometry [20].

\section{Endpoints}

The primary endpoint was EFS. An event was defined as one of the following: death from any cause; presence of radiographic progression AND symptomatic/clinical progression; presence of radiographic progression AND PSA progression; presence of symptomatic/clinical progression AND PSA progression. Radiographic progression included progression on bone scan or soft tissue disease progression according to PCWG2 criteria or modified RECIST 1.1. Radiographic assessments were performed at the local sites. Symptomatic/ clinical progression was defined as occurrence of a skeletal related event due to bone metastases (defined as pathologic fracture, spinal cord compression, palliative radiation to bone or surgery to bone); physician decision for intervention due to new disease related complications (e.g., urinary obstruction, hydronephrosis); physician decision to initiate new systemic anticancer therapy or progressive disease related pain despite adequate analgesic treatment. PSA progression was defined as a $\geq 25 \%$ increase over baseline (if no PSA decline on trial treatment), $\geq 25 \%$ increase over the nadir (if PSA response to treatment $<50 \%$ ) or a $\geq 50 \%$ increase over the nadir (if PSA response to treatment was $\geq 50 \%$ ). In any case an absolute PSA increase of $\geq 5 \mathrm{ng} / \mathrm{ml}$ was required and PSA progression had to be confirmed at the next assessment.

Secondary endpoints included OS, radiographic progression-free survival (rPFS), time to PSA progression, PSA response $(30 \%, 50 \%, 90 \%$, and best), QoL and pain response as well as evaluation of adverse events (according to Common Terminology Criteria for Adverse Events version 4.0; CTCAE v4.0).

The primary QoL endpoint was the change from baseline in FACT-P total score across the whole observation period.

To assess the apparent CYP17 blockade, precursorto-product metabolite ratios [21] were derived from steroid measurements (Fig. 4).

\section{Statistical Analysis}

Sample size was calculated based on the primary endpoint of EFS. It was planned to randomize 192 patients (96 in each arm) to detect an improvement in EFS to 6.67 months in the experimental arm compared to 4 months in the placebo arm (hazard ratio (HR) $=0.6$ ) with a type I error of $5 \%$ and a power of $90 \%$. The number of events required for primary analysis was 163. An interim efficacy analysis was planned after 65 events. All analyses were based on the intention-to-treat (ITT) population. All time-to-event endpoints were calculated from randomization until event of interest. Patients not experiencing an event were censored at the last available assessment or at initiation of a different treatment or at the date of unblinding. The medians and corresponding confidence intervals (CI) were estimated using the KaplanMeier method and compared between treatment arms 
using log-rank tests. The HRs were estimated using Cox models. Due to the small number of samples the QoL endpoints were only analyzed descriptively using median and quartiles as well as boxplots. To assess the apparent CYP17A1 activity, ratios 1 and 2 were log-transformed and compared descriptively between treatment arms using line plots and associated with PSA response using waterfall plots.

Two-tailed tests with a significance level of 0.05 were used for all analyses. As no adjustment for multiple testing was applied for analyses other than the primary endpoint analysis, they were exploratory and hypothesis generating. All analyses were performed using SAS 9.2 (SAS Institute) and R 3.0.3 (http://www.r-project.org).

\section{RESULTS \\ Patient Characteristics}

In June 2014, the manufacturer announced to stop further development of orteronel in prostate cancer due to negative results of two phase III trials $[6,7,22]$. Due to this decision the present trial was prematurely closed in July 2014. A total of 47 patients were randomized between November 9, 2012 and July 17, 2014. Twenty three patients were randomized to the orteronel arm and 24 to the placebo arm. All randomized patients are included in the ITT population and are reported here.

The two groups were generally well balanced for baseline demographic and clinical characteristics (Table I).

\section{Efficacy}

Median treatment duration with orteronel was 5.1 months (range 2.7-10.2) compared to 2.8 months (range 2.0-4.2) in the placebo arm. The main reasons for discontinuation of treatment were disease progression, patient refusal and toxicity for $14(61 \%), 4(17 \%)$, and $3(13 \%)$ patients on orteronel compared to $20(83 \%), 4(17 \%)$, and $0(0 \%)$ patients on placebo, respectively (Fig. 1).

Median follow up was 17 months in the orteronel arm and 18.4 months in the placebo arm. The primary endpoint was reached with a median EFS of 8.5 months (95\%CI 3.2-16.0) on orteronel compared to 2.9 months $(95 \%$ CI $2.7-3.9)$ on placebo $(P=0.001$, HR 0.32; 95\%CI 0.15-0.65) (Fig. 2A). The secondary endpoint median rPFS was 8.5 months $(95 \% \mathrm{CI}$ 3.5-14.2) on orteronel and 2.8 months (95\%CI 2.7-5.6) on placebo $(P=0.02, \mathrm{HR} \quad 0.42 ; 95 \% \mathrm{CI} \quad 0.20-0.91)$ (Fig. 2B). All efficacy results are summarized in Table II (see also Suppl. Fig. S1). The waterfall plot for PSA response on trial treatment is shown in Figure 3.
TABLE I. Demographical and Clinical Patient Characteristics at Baseline

\begin{tabular}{|c|c|c|}
\hline & $\begin{array}{c}\text { Arm A } \\
\text { (Orteronel) } \\
\mathrm{N}=23\end{array}$ & $\begin{array}{l}\text { Arm B } \\
\text { (Placebo) } \\
\mathrm{N}=24\end{array}$ \\
\hline Age, years, median (IQR) & $70(61-74)$ & $70.5(66-76.5)$ \\
\hline \multicolumn{3}{|l|}{ WHO PS } \\
\hline PS 0 & $13(57 \%)$ & $12(50 \%)$ \\
\hline PS 1 & $9(39 \%)$ & $11(46 \%)$ \\
\hline PS 2 & $1(4 \%)$ & $1(4 \%)$ \\
\hline \multicolumn{3}{|l|}{ Gleason score } \\
\hline Score $5-7$ & $5(22 \%)$ & $6(25 \%)$ \\
\hline Score 8-10 & $14(61 \%)$ & $15(62 \%)$ \\
\hline Missing & $4(17 \%)$ & $3(13 \%)$ \\
\hline \multicolumn{3}{|l|}{ Site of metastases } \\
\hline Bone & $20(87 \%)$ & $17(71 \%)$ \\
\hline Lymph nodes & $12(52 \%)$ & $15(63 \%)$ \\
\hline Lung & $3(13 \%)$ & $2(8 \%)$ \\
\hline Liver & $2(9 \%)$ & $1(4 \%)$ \\
\hline Other & $4(17 \%)$ & $6(25 \%)$ \\
\hline \multicolumn{3}{|l|}{ Response to docetaxel } \\
\hline Stable disease & $11(48 \%)$ & $9(37 \%)$ \\
\hline Partial response & $12(52 \%)$ & $15(63 \%)$ \\
\hline $\begin{array}{l}\text { Cumulative dose of } \\
\text { docetaxel, } \mathrm{mg} / \mathrm{m}^{2}, \\
\text { median (IQR) }\end{array}$ & $450(400-673)$ & $510(443-600)$ \\
\hline $\begin{array}{l}\text { Time from last docetaxel to } \\
\text { study treatment, days, } \\
\text { median (IQR) }\end{array}$ & $36(29-41)$ & $35.5(30.5-40)$ \\
\hline
\end{tabular}

Nearly $80 \%$ of the patients in both arms received at least one further systemic treatment. Subsequent treatments after discontinuation of trial treatment are summarized in Table III. Since only a few deaths have occurred OS data is not mature.

\section{Adverse Events}

All related adverse events during or within 30 days of termination of trial treatment are summarized in Table IV. One patient receiving orteronel experienced adrenal insufficiency (grade 3) with uncertain causal relationship to trial drug as he had undergone prednisone tapering in the days before admission. He recovered quickly on reintroduction of prednisone. One further patient on orteronel suffered grade 4 pneumonitis that was classified as probably related to trial drug. He had a full recovery after drug discontinuation.

\section{Quality of Life and Pain Assessment}

Twenty-two patients in the orteronel arm and 23 in the placebo arm completed the baseline and at least 


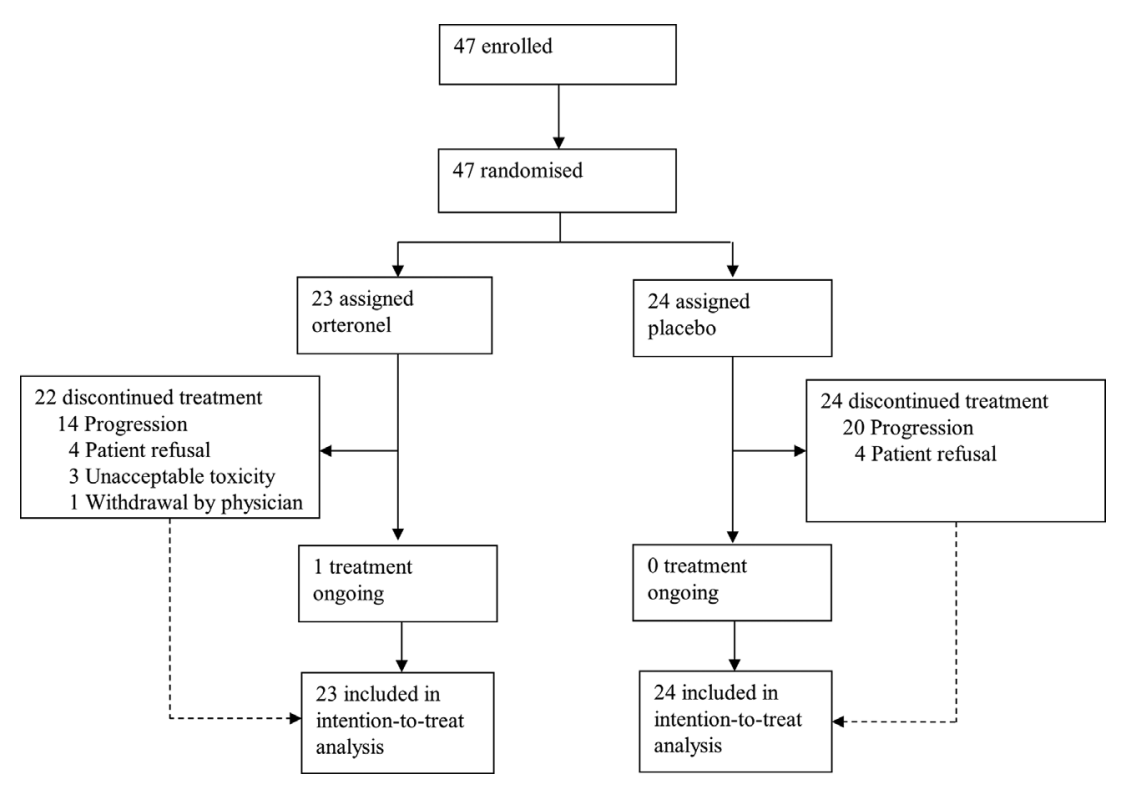

Fig. I. Trial profile.

one subsequent questionnaire for QoL and pain. The two treatment arms indicated similar changes in FACT-P total scores (Suppl. Fig. S2). The secondary
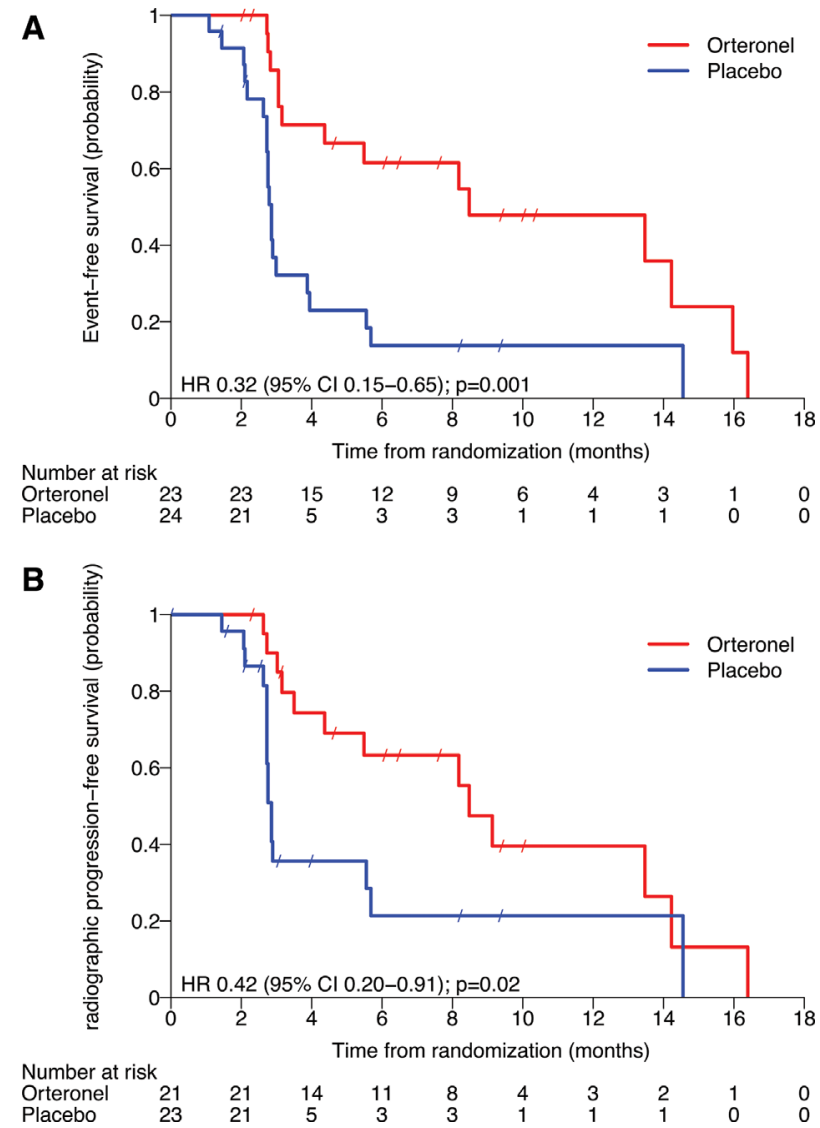

Fig. 2. Kaplan-Meier plots for event-free survival (EFS) (A) and radiographic progression-free survival (rPFS) (B).
QoL endpoints showed consistent findings. However, the number of patients providing data was small and decreasing continuously. Thus, no meaningful analysis of pain over the course of treatment was possible.

\section{Urinary Metabolites in Relation to Trial Treatment}

The log-transformed ratios of urinary steroid hormones showed a definite blockade of CYP17 for all patients on orteronel (Fig. 4).

No clear association between the level of CYP17 inhibition and PSA response was found (Suppl. Fig. S3). The same applies to the association between the level of CYP17 inhibition and EFS or rPFS. The sample size however is very small and does not allow to answer this question.

\section{DISCUSSION}

In standard practice, men with mCRPC completing chemotherapy with docetaxel are followed clinically until disease progression, since all reported positive phase III trials post docetaxel included only patients with documented disease progression. Maintenance treatment, either as continuation of a drug already given concomitantly from the start of first line chemotherapy or a drug introduced after disease stabilization by first line chemotherapy (switch maintenance therapy), has been shown to improve outcome in several other malignancies.

Maintenance therapy with one of the novel endocrine agents following docetaxel is attractive as they are generally well tolerated but this concept has not 
TABLE II. Overview of Efficacy Results

\begin{tabular}{|c|c|c|c|}
\hline Endpoint & Orteronel $(\mathrm{N}=23)$ & Placebo $(\mathrm{N}=24)$ & $\begin{array}{l}P \text {-value, HR } \\
\quad(95 \% \mathrm{CI})\end{array}$ \\
\hline Event-free survival (EFS), median $(95 \% \mathrm{CI})$ & 8.5 months $(3.2-16)$ & 2.9 months $(2.7-3.9)$ & $\begin{array}{c}P=0.001^{\mathrm{a}}, 0.32 \\
(0.15-0.65)\end{array}$ \\
\hline $\begin{array}{l}\text { Radiographic progression-free survival (rPFS), } \\
\text { median }(95 \% \mathrm{CI})\end{array}$ & 8.5 months $(3.5-14.2)$ & 2.8 months $(2.7-5.6)$ & $\begin{array}{l}P=0.02^{\mathrm{a}}, 0.42 \\
\quad(0.20-0.91)\end{array}$ \\
\hline Time to PSA progression, median $(95 \% \mathrm{CI})$ & 6.5 months $(2.7-10.3)$ & 1.8 months (1.1-2.9) & $\begin{array}{c}P=0.004^{\mathrm{a}}, 0.37 \\
(0.18-0.75)\end{array}$ \\
\hline $\begin{array}{l}\text { Time to radiographic progression from last } \\
\text { docetaxel dose, median }(95 \% \mathrm{CI})\end{array}$ & 9.6 months $(5.3-15.0)$ & 4.0 months $(3.7-6.4)$ & - \\
\hline $\begin{array}{l}\text { Time to symptomatic/clinical progression, } \\
\text { median }(95 \% \mathrm{CI})\end{array}$ & 14.4 months $\left(4.4-\mathrm{NR}^{\mathrm{b}}\right)$ & 3.0 months $(2.8-5.7)$ & - \\
\hline PSA decline $\geq 30 \%$, n (\%) $(95 \% \mathrm{CI})$ & $17(74 \%)(52-90 \%)$ & $2(8 \%)(1-27 \%)$ & $<0.001^{\mathrm{c}}$ \\
\hline PSA decline $\geq 50 \%$, n (\%) $(95 \% \mathrm{CI})$ & $13(57 \%)(35-77 \%)$ & $1(4 \%)(0-21 \%)$ & $<0.001^{\mathrm{c}}$ \\
\hline PSA decline $\geq 90 \%$, n (\%) $(95 \% \mathrm{CI})$ & $2(9 \%) \quad(1-28 \%)$ & $0(0 \%)$ & - \\
\hline
\end{tabular}

${ }^{\mathrm{a}}$ Log-rank test.

${ }^{\mathrm{b}} \mathrm{NR}$, not reached.

'Fisher's exact test.

so far been investigated for mCRPC. Despite the fact that this trial had to be prematurely closed after the inclusion of 47 of 192 planned patients due to the manufacturer's decision to abrogate further development of the CYP17 inhibitor orteronel for prostate cancer, there was a significant improvement in EFS and rPFS. The rPFS of 8.5 months found in our trial is comparable to other novel agents used in second line after prior docetaxel: rPFS on abiraterone/prednisone was 5.6 months [2], on enzalutamide 8.3 months [3] and on orteronel $(400 \mathrm{mg} \mathrm{bd}) /$ prednisone 8.3 months [6], respectively. In view of the fact that the patients in our trial were selected in the sense that they all had derived clinical benefit from docetaxel (PR or SD) and due to the small number of patients included the results have to be interpreted with caution.

The patient population included in our trial was different from all other trials with novel endocrine

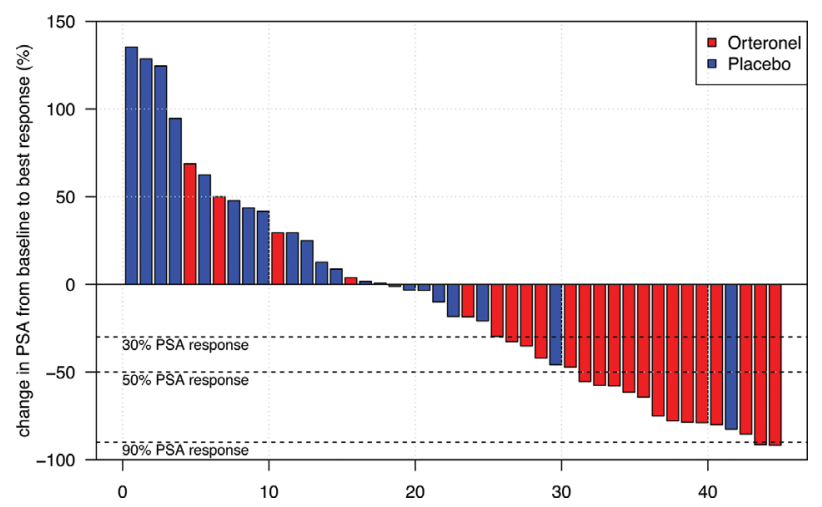

Fig. 3. Waterfall plot for best PSA response on treatment. agents: in this trial patients had to have non-progressive disease after docetaxel treatment and trial treatment was planned to start 3-6 weeks after last application of docetaxel. Median docetaxel dose was $450 \mathrm{mg} / \mathrm{m}^{2}$ corresponding to six cycles of 3-weekly docetaxel. None of the patients had received either

TABLE III. Subsequent Therapies After Discontinuation of Trial Treatment

\begin{tabular}{|c|c|c|}
\hline & $\begin{array}{l}\text { Orteronel } \\
(\mathrm{N}=23)\end{array}$ & $\begin{array}{l}\text { Placebo } \\
(\mathrm{N}=24)\end{array}$ \\
\hline Variable & $\mathrm{n}(\%)$ & n $(\%)$ \\
\hline \multicolumn{3}{|l|}{ Subsequent treatment } \\
\hline Yes & $18(78)$ & $19(80)$ \\
\hline No & $3(13)$ & $2(8)$ \\
\hline Orteronel ongoing & $1(4)$ & $0(0)$ \\
\hline Unknown & $1(4)$ & $3(13)$ \\
\hline Abiraterone or Enzalutamide & $16(70)$ & $15(63)$ \\
\hline \multicolumn{3}{|l|}{$\begin{array}{l}\text { Specify subsequent treatment } \\
\text { (more than one applicable) }\end{array}$} \\
\hline Abiraterone & $10(44)$ & $11(46)$ \\
\hline Cabazitaxel & $10(44)$ & $8(33)$ \\
\hline Carboplatin & $4(17)$ & $0(0)$ \\
\hline Dexamethasone & $0(0)$ & $2(8)$ \\
\hline Docetaxel & $4(17)$ & $3(13)$ \\
\hline Enzalutamide & $9(39)$ & $9(38)$ \\
\hline Epirubicin & $1(4)$ & $0(0)$ \\
\hline Etoposide & $1(4)$ & $0(0)$ \\
\hline Paclitaxel & $3(13)$ & $0(0)$ \\
\hline Prednisone & $0(0)$ & $1(4)$ \\
\hline Radium-223 & $4(17)$ & $3(13)$ \\
\hline Stilboestrol & $1(4)$ & $0(0)$ \\
\hline
\end{tabular}


TABLE IV. Adverse Events Under Treatment and Until 30 Days After Treatment Stop or Start of New Treatment That Are Possibly, Probably, or Definitely Related to Trial Treatment

\begin{tabular}{|c|c|c|c|c|c|c|c|}
\hline \multirow[b]{2}{*}{ AE category } & \multicolumn{4}{|c|}{ Orteronel $(\mathrm{N}=23)$} & \multicolumn{3}{|c|}{ Placebo $(\mathrm{N}=24)$} \\
\hline & $\begin{array}{c}\text { Grade } 1, \mathrm{n} \\
(\%)\end{array}$ & $\begin{array}{c}\text { Grade } 2, \mathrm{n} \\
(\%)\end{array}$ & $\begin{array}{c}\text { Grade } 3, \mathrm{n} \\
(\%)\end{array}$ & $\begin{array}{l}\text { Grade } 4, \mathrm{n} \\
(\%)\end{array}$ & $\begin{array}{c}\text { Grade } 1, \mathrm{n} \\
(\%)\end{array}$ & $\begin{array}{c}\text { Grade } 2, \mathrm{n} \\
(\%)\end{array}$ & $\begin{array}{c}\text { Grade 3, n } \\
\text { (\%) }\end{array}$ \\
\hline Adrenal insufficiency & & & $1(4)$ & & & & \\
\hline Anemia & & $1(4)$ & & & & & \\
\hline Cardiac disorders & & & & & & $1(4)$ & \\
\hline Creatinine increased & $1(4)$ & & & & & & \\
\hline Elevated liver enzymes & & $1(4)$ & & & & & $1(4)$ \\
\hline Fatigue & $2(9)$ & $4(17)$ & $2(9)$ & & $2(8)$ & & \\
\hline GGT increased & & $1(4)$ & & & & & \\
\hline $\begin{array}{l}\text { Gastrointestinal } \\
\text { disorders }\end{array}$ & $8(35)$ & $3(13)$ & $1(4)$ & & $2(8)$ & $1(4)$ & $1(4)$ \\
\hline Genital edema & & & & & & & $1(4)$ \\
\hline Hot flashes & $3(13)$ & & & & & $1(4)$ & \\
\hline Hypertension & & $3(13)$ & & & & & $2(8)$ \\
\hline Hypokalemia & $1(4)$ & & $1(4)$ & & & & \\
\hline Infection & $1(4)$ & & & & & $2(8)$ & \\
\hline $\begin{array}{l}\text { Lipase/amylase } \\
\text { increased }\end{array}$ & & & $1(4)$ & & & & \\
\hline Muscle weakness & $1(4)$ & & & & & & \\
\hline Nausea/vomiting & $4(17)$ & $6(26)$ & & & $2(8)$ & & $1(4)$ \\
\hline Neurological disorders & $3(13)$ & $3(13)$ & & & & & $1(4)$ \\
\hline Pain & $4(17)$ & & & & & $1(4)$ & \\
\hline Peripheral edema & $2(9)$ & & & & $2(8)$ & $1(4)$ & \\
\hline Psychiatric disorders & $1(4)$ & & $1(4)$ & & & & \\
\hline Pulmonary disorders & & $1(4)$ & & $1(4)$ & & $1(4)$ & \\
\hline QTc prolongation & & & $1(4)$ & & & & \\
\hline
\end{tabular}

abiraterone or enzalutamide prior to chemotherapy. This limits the applicability of our results in the current treatment landscape but our trial provides evidence for a proof of concept that needs to be tested for patients with prior exposure to API's in forthcoming trials.

We used a different orteronel dose than in the phase 3 trials [6,7]: instead of $400 \mathrm{mg}$ BID plus low dose prednisone only $300 \mathrm{mg}$ BID without prednisone were administered. This approach was based on results from two trials demonstrating that orteronel doses of $300 \mathrm{mg}$ BID without prednisone appeared equally effective not only in terms of suppression of measurable androgen synthesis but also in terms of clinical response $[23,24]$.

The patients in the control arm of our trial received placebo without prednisone. Most patients included had received low-dose prednisone with prior docetaxel and investigators were encouraged to taper prednisone before trial inclusion. However, some misbalance in the use of low-dose prednisone cannot be excluded since it was not used as a stratification criterion. From a clinical point of view, it appears unlikely that a possible misbalance might have significantly changed the results. Likewise, a misbalance in the use of bone targeting agents (e.g., denosumab or zoledronic acid) cannot be excluded. However, none of these agents has demonstrated any impact on efficacy endpoints in several large trials and hence an impact on the results presented appears unlikely.

In the placebo arm, we demonstrated that patients who benefitted from docetaxel have only a 4 months median time to radiographic progression from last docetaxel administration. This suggests that interrupting all treatment (apart from baseline castration) in mCRPC patients allows tumor cells to regrow quickly. Also, the median time to clinical/symptomatic progression of 3 months in the placebo arm is short. Introducing a generally well tolerated, efficacious therapy with another mechanism of action at this earlier time point may therefore lead to clinical benefit. The QoL data were not conclusive due to high interpatient variability and the small number of patients. Of note, the frequency of symptomatic/ clinical progression was lower in the orteronel arm and the events occurred much later indicating a possible QoL benefit if treatment with an API is initiated early after the end of chemotherapy instead 


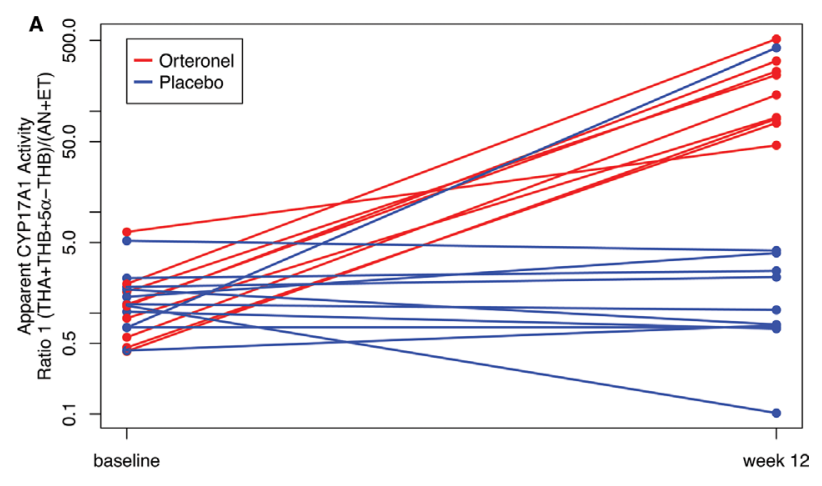

B

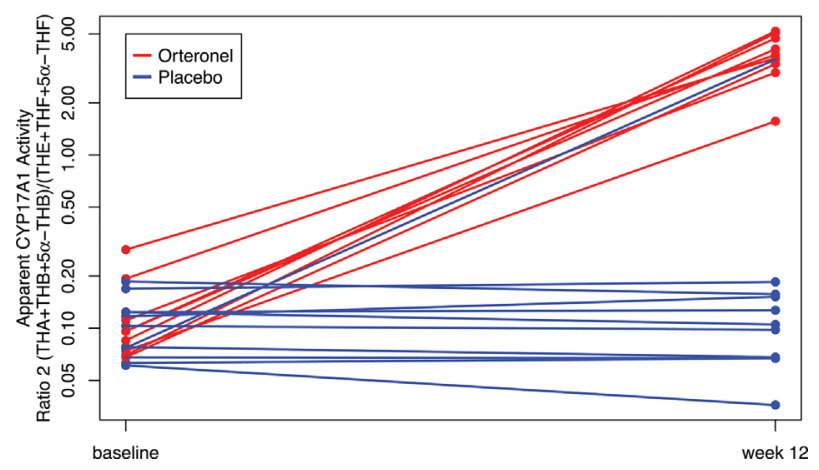

Fig. 4. Apparent CYPI7AI blockade before treatment and 12 weeks after treatment start assessed by log-transformed ratio I (A) and 2 (B). The following precursor-to-product metabolite ratios were derived: ratio I [tetrahydro- I I-dehydrocorticosterone $(T H A)+$ tetrahydrocorticosterone $(T H B)+5 \alpha$-tetrahydrocorticosterone $(5 \alpha-\mathrm{THB})] /[$ androsterone $(\mathrm{An})+$ etiocholanolone (Et)] and ratio $2[\mathrm{THA}+\mathrm{THB}+5 \alpha-\mathrm{THB}] /[$ tetrahydrocortisone (THE) + tetrahydrocortisol (THF) $+5 \alpha$-tetrahydrocortisol $(5 \alpha$ THF)].

of deferred. Our trial however cannot answer the question whether early initiation of novel API's after chemotherapy compared to starting treatment at time of progression is beneficial for patients in terms of overall survival. The results of the two trials testing the API's abiraterone and enzalutamide before the use of docetaxel demonstrate that using novel API's early in asymptomatic patients can improve OS [4,5]. Trials are ongoing where API's are tested early in hormonesensitive metastatic prostate cancer.

The downstream urine metabolites in all patients on orteronel were consistent with blockage of the target enzyme CYP17, a correlation of the degree of inhibition with response could not be seen, but the number of samples was small. This non-invasive approach could potentially be developed for testing adherence to therapy for this class of oral drugs.

Of note, high PSA response rates were seen on orteronel in our trial with patients who were stable or responding to docetaxel. This suggests an ongoing dependency on the androgen receptor pathway contradicting a postulated cross-resistance between docetaxel and novel APIs as was also demonstrated in the post-docetaxel trials using abiraterone or enzalutamide $[2,3]$.

To conclude, our trial showed that early use of an API like orteronel in men achieving disease stabilization on docetaxel significantly prolongs EFS. However, if this translates into improved QoL or a benefit in OS remains to be proven. Our trial despite all its limitations clearly establishes a rationale to further develop the approach of immediate switch maintenance after successful completion of chemotherapy.

\section{ACKNOWLEDGMENTS}

We thank all the patients who participated in the trial and their families. We thank Arnoud Templeton for helping with development of the trial protocol and for critical reading of the manuscript. We thank Howard Scher for fruitful and critical discussion of the data.

\section{REFERENCES}

1. Tannock IF, de Wit R, Berry WR, Horti J, Pluzanska A, Chi KN, Oudard S, Theodore C, James ND, Turesson I, Rosenthal MA, Eisenberger MA. Docetaxel plus prednisone or mitoxantrone plus prednisone for advanced prostate cancer. N Engl J Med 2004;351:1502-1512.

2. de Bono JS, Logothetis CJ, Molina A, Fizazi K, North S, Chu L, Chi KN, Jones RJ, Goodman OB Jr., Saad F, Staffurth JN, Mainwaring P, Harland S, Flaig TW, Hutson TE, Cheng T, Patterson H, Hainsworth JD, Ryan CJ, Sternberg CN, Ellard SL, Flechon A, Saleh M, Scholz M, Efstathiou E, Zivi A, Bianchini D, Loriot Y, Chieffo N, Kheoh T, Haqq CM, Scher HI. Abiraterone and increased survival in metastatic prostate cancer. N Engl J Med 2011;364:1995-2005.

3. Scher HI, Fizazi K, Saad F, Taplin ME, Sternberg CN, Miller K, de Wit R, Mulders P, Chi KN, Shore ND, Armstrong AJ, Flaig TW, Flechon A, Mainwaring P, Fleming M, Hainsworth JD, Hirmand M, Selby B, Seely L, de Bono JS. Increased survival with enzalutamide in prostate cancer after chemotherapy. N Engl J Med 2012;367:1187-1197.

4. Beer TM, Armstrong AJ, Rathkopf DE, Loriot Y, Sternberg CN, Higano CS, Iversen P, Bhattacharya S, Carles J, Chowdhury S, Davis ID, de Bono JS, Evans CP, Fizazi K, Joshua AM, Kim CS, Kimura G, Mainwaring P, Mansbach H, Miller K, Noonberg SB, Perabo F, Phung D, Saad F, Scher HI, Taplin ME, Venner PM, Tombal B. Enzalutamide in metastatic prostate cancer before chemotherapy. N Engl J Med 2014;371:424-433.

5. Ryan CJ, Smith MR, de Bono JS, Molina A, Logothetis CJ, de Souza P, Fizazi K, Mainwaring P, Piulats JM, Ng S, Carles J, Mulders PF, Basch E, Small EJ, Saad F, Schrijvers D, Van Poppel H, Mukherjee SD, Suttmann H, Gerritsen WR, Flaig TW, George DJ, Yu EY, Efstathiou E, Pantuck A, Winquist E, Higano CS, Taplin ME, Park Y, Kheoh T, Griffin T, Scher HI, Rathkopf DE. Abiraterone in metastatic prostate cancer without previous chemotherapy. N Engl J Med 2013;368:138-148. 
6. Fizazi K, Jones R, Oudard S, Efstathiou E, Saad F, de Wit R, De Bono J, Cruz FM, Fountzilas G, Ulys A, Carcano F, Agarwal N, Agus D, Bellmunt J, Petrylak DP, Lee SY, Webb IJ, Tejura B, Borgstein N, Dreicer R. Phase III, randomized, double-blind, multicenter trial comparing orteronel (TAK-700) plus prednisone with placebo plus prednisone in patients with metastatic castration-resistant prostate cancer that has progressed during or after docetaxel-based therapy: ELM-PC 5. J Clin Oncol 2015;33:723-731.

7. Saad F, Fizazi K, Jinga V, Efstathiou E, Fong PC, Hart LL, Jones R, McDermott R, Wirth M, Suzuki K, MacLean DB, Wang L, Akaza H, Nelson J, Scher HI, Dreicer R, Webb IJ, de Wit R. Orteronel plus prednisone in patients with chemotherapy-naive metastatic castration-resistant prostate cancer (ELM-PC 4): A double-blind, multicentre, phase 3, randomised, placebocontrolled trial. Lancet Oncol 2015;16:338-348.

8. Ciuleanu T, Brodowicz T, Zielinski C, Kim JH, Krzakowski M, Laack E, Wu YL, Bover I, Begbie S, Tzekova V, Cucevic B, Pereira JR, Yang SH, Madhavan J, Sugarman KP, Peterson P, John WJ, Krejcy K, Belani CP. Maintenance pemetrexed plus best supportive care versus placebo plus best supportive care for non-small-cell lung cancer: A randomised, double-blind, phase 3 study. Lancet 2009;374:1432-1440.

9. Cappuzzo F, Ciuleanu T, Stelmakh L, Cicenas S, Szczesna A, Juhasz E, Esteban E, Molinier O, Brugger W, Melezinek I, Klingelschmitt G, Klughammer B, Giaccone G. Erlotinib as maintenance treatment in advanced non-small-cell lung cancer: A multicentre, randomised, placebo-controlled phase 3 study. Lancet Oncol 2010;11:521-529.

10. Declaration of Helsinki (as amended in Tokyo, Venice, Hong Kong, Somerset West, Edinburgh, Seoul and Fortaleza, and clarified in Washington and Tokyo). 2013, October. In: http:// www.wma.net/en/30publications/10policies/b3/index.html.p df?print-media-type\&footer-right $=[$ page $] /[$ toPage $]$

11. International Conference on Harmonization (ICH) (1996) E 6 Guideline for Good Clinical Practice. In: http://www.ich.org/ fileadmin/Public_Web_Site/ICH_Products/Guidelines/Efficac y/E6/E6_R1_Guideline.pdf

12. Directive 2001/20/EC of the European parliament and of the council In: http://www.eortc.be/Services/Doc/clinical-EUdirective-04-April-01.pdf; 2001.

13. Verordnung über klinische Versuche in der Humanforschung (Verordnung über klinische Versuche; KlinV) vom 20. September 2013 (Stand am 1. Januar 2014) / Ordonnance sur les essais cliniques dans le cadre de la recherche sur l'être humain (Ordonnance sur les essais cliniques, OClin) du 20 septembre 2013 (Etat le 1er janvier 2014), 810.305. In: Government, ed.: http://www.admin.ch/opc/de/classified-compilation/201211 76/201401010000/810.305.pdf

14. HRA. Bundesgesetz über die Forschung am Menschen (Humanforschungsgesetz, HFG) vom 30. September 2011 (Stand am 1. Januar 2014) / Loi fédérale relative à la recherche sur l'être humain (Loi relative à la recherche sur l'être humain, LRH) du 30 septembre 2011 (Etat le 1er janvier 2014), 810.30. In: Goverment, ed.: http://www.admin.ch/opc/de/officialcompilation/2013/3215.pdf

15. Organisationsverordnung zum Humanforschungsgesetz (Organisationsverordnung HFG, OV-HFG) vom 20. September 2013 (Stand am 1. Januar 2014) / Ordonnance d'organisation concernant la loi relative à la recherche sur l'être humain
(Ordonnance d'organisation concernant la LRH, Org LRH) du 20 septembre 2013 (Etat le 1er janvier 2014), 810.308. In: Government, ed.: http://www.admin.ch/opc/de/classifiedcompilation/20121179/201401010000/810.308.pdf

16. Verordnung über die Humanforschung mit Ausnahme der klinischen Versuche (Humanforschungsverordnung, HFV) vom 20. September 2013 (Stand am 1. Januar 2014) / Ordonnance relative à la recherche sur l'être humain à l'exception des essais cliniques (Ordonnance relative à la recherche sur l'être humain, ORH) du 20 septembre 2013 (Etat le 1er janvier 2014), 810.301. In: http://www.admin.ch/opc/de/official-compilation/2013/ 3381.pdf

17. Scher HI, Halabi S, Tannock I, Morris M, Sternberg $\mathrm{CN}$, Carducci MA, Eisenberger MA, Higano C, Bubley GJ, Dreicer R, Petrylak D, Kantoff P, Basch E, Kelly WK, Figg WD, Small EJ, Beer TM, Wilding G, Martin A, Hussain M. Design and end points of clinical trials for patients with progressive prostate cancer and castrate levels of testosterone: Recommendations of the Prostate Cancer Clinical Trials Working Group. J Clin Oncol 2008;26:1148-1159.

18. Esper P, Mo F, Chodak G, Sinner M, Cella D, Pienta KJ. Measuring quality of life in men with prostate cancer using the functional assessment of cancer therapy-prostate instrument. Urology 1997;50:920-928.

19. Bernhard J, Maibach R, Thurlimann B, Sessa C, Aapro MS. Patients' estimation of overall treatment burden: Why not ask the obvious? J Clin Oncol 2002;20:65-72.

20. Shackleton $\mathrm{CH}$. Mass spectrometry in the diagnosis of steroidrelated disorders and in hypertension research. J Steroid Biochem Mol Biol 1993;45:127-140.

21. Ackermann D, Pruijm M, Ponte B, Guessous I, Ehret G, Escher G, Dick B, Al-Alwan H, Vuistiner P, Paccaud F, Burnier M, Pechere-Bertschi A, Martin PY, Vogt B, Mohaupt M, Bochud M. CYP17A1 enzyme activity is linked to ambulatory blood pressure in a family-based population study. Am J Hypertens 2016;29(4):484-493.

22. Millennium/Takeda News Releases: Takeda Announces Termination of Orteronel (TAK-700) Development for Prostate Cancer in Japan, U.S.A. and Europe (June 19, 2014), http:/ /investor.mil lennium.com/phoenix.zhtml?c $=80159 \& p=$ irol-newsArticle\& ID $=1940905 \&$ highlight $=$.In

23. Dreicer R, MacLean D, Suri A, Stadler WM, Shevrin D, Hart L, MacVicar GR, Hamid O, Hainsworth J, Gross ME, Shi Y, Webb IJ, Agus DB. Phase I/II trial of orteronel (TAK-700)-an investigational 17,20-lyase inhibitor-in patients with metastatic castration-resistant prostate cancer. Clin Cancer Res 2014;20: 1335-1344.

24. Hussain M, Corn PG, Michaelson MD, Hammers HJ, Alumkal JJ, Ryan CJ, Bruce JY, Moran S, Lee SY, Lin HM, George DJ. Phase II study of single-agent orteronel (TAK-700) in patients with nonmetastatic castration-resistant prostate cancer and rising prostate-specific antigen. Clin Cancer Res 2014;20:4218-4227.

\section{SUPPORTING INFORMATION}

Additional supporting information may be found in the online version of this article at the publisher's web-site. 